\title{
Wonen en werken in de Late IJzertijd in Spijkenisse Archaeology
}

\author{
Linda P. Verniers (depositor) \\ ADC ArcheoProjecten \\ l.verniers@archeologie.nl \\ Rene Torremans (depositor) \\ ArcheologieAdvies \\ rene.torremans@archeologieadvies.nl
}

\begin{abstract}
In July 2009, part of a stable farm from the end of the 3rd century вС at Spijkenisse was excavated. This farm was at the time situated in wet grassland with rough vegetation used as pasture. The excavated house plan consists of a living area, a hall and a stable part. After the occupation phase (around 210-200 BC) the site was used as a craft zone for beer or glue production (beginning of the 2nd century вC). In the archaeological research, attention was paid to the finding level (whether or not consecutively), the phasing in the tracks, the raw material supply and the food economy. The data concerning the pottery is entered in a Microsoft Access database. The hand-formed pottery found can be roughly dated as late Middle Iron Age and Late Iron Age. The majority of the animal component of the diet consisted of meat from domestic animals (especially beef, and also meat of sheep and/or goat). Emmer wheat and barley are the most important ingredients in the grain macro residues from the hearths. The habitation of the residential stable farm will have lasted about 10 to a maximum of 20 years. The next generation may have built a new farm in the vicinity.
\end{abstract}

\section{Keywords}

archaeology data - woonstalboerderij - Late Iron Age 


\section{Introductie}

\subsection{De opgraving}

Tijdens een opgraving in Spijkenisse is door ADC ArcheoProjecten in juli 2009 een deel van een woonstalboerderij opgegraven. De opgraving werd uitgevoerd in opdracht van Waterschap Hollandse Delta, in het kader van een verbetering van de waterhuishouding op Putten. De woonstalboerderij kan aan het einde van de ze eeuw v. Chr. gedateerd worden. Deze boerderij bevond zich haaks op de huidige rivier de Dalle, aan de zuidzijde van Spijkenisse. Na de bewoningsfase is de vindplaats in gebruik geweest als ambachtszone. De elf aangetroffen haarden of stookplaatsen, in combinatie met het vondstmateriaal, wijzen op een locale productie van mogelijk bier of lijm.

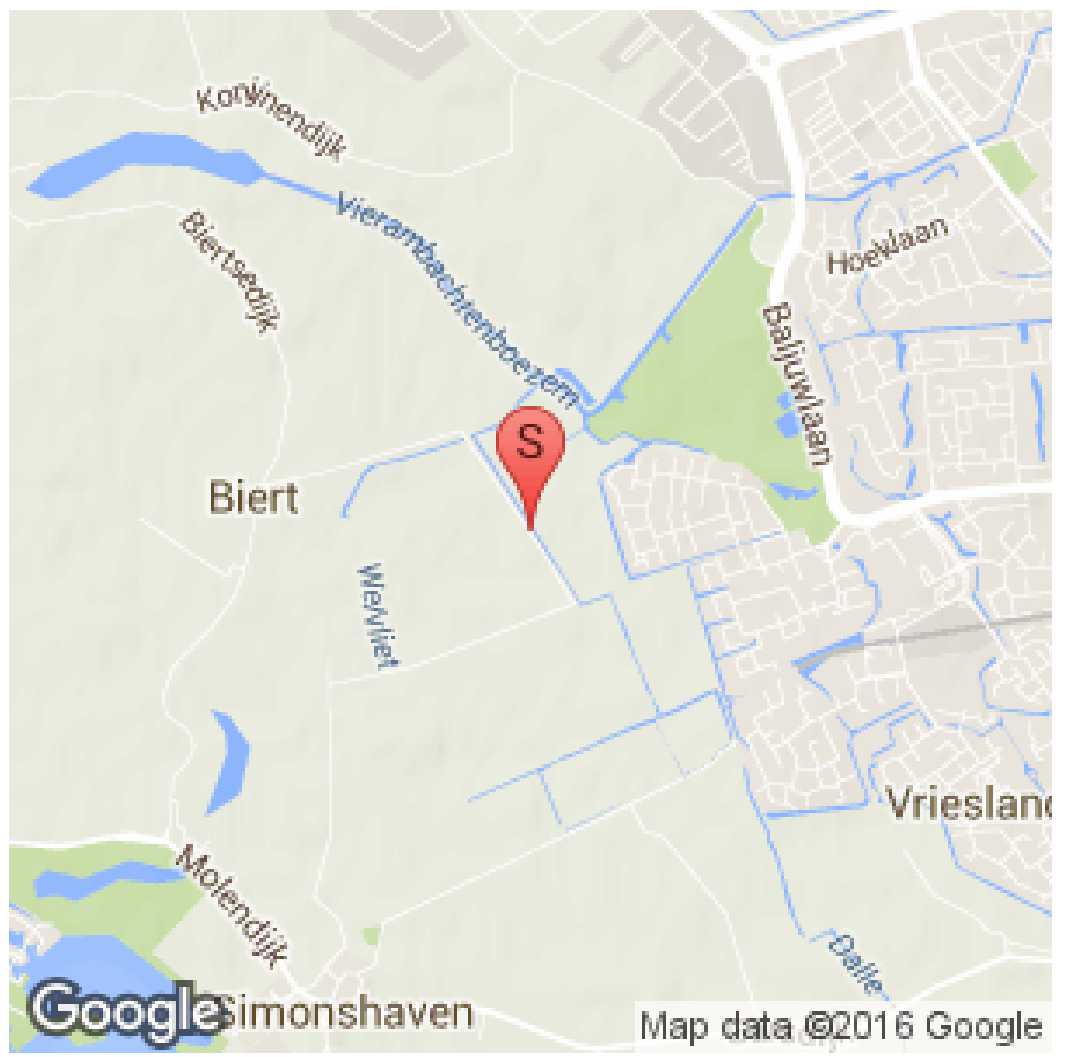

AFBEELDING 1 Locatie van de opgraving bij rivier De Dalle, aan de Slikweg $(S)$. 


\subsection{De woonstalboerderij}

Op de vindplaats is een deel van een woonstalboerderij aangetroffen. Deze bevindt zich haaks op de huidige rivier de Dalle, waarbij het westelijk deel van de boerderij is verdwenen vanwege de rivier. Het oostelijk deel is, op basis van een haard, het woondeel. Ten westen hiervan bevindt zich een hal, waar de ingangen van het huis hebben gelegen. De westzijde van het huis zal zijn gevormd door een stal. De plattegrond is oorspronkelijk drie- en vierschepig; door een latere toevoeging van een nokpaal in het woondeel, ontstaat hier een tweeschepig deel. De buitenstijlen en één van de nokstijlen zijn latere toevoegingen geweest, ter versteviging van de bestaande constructie. Ook in de wanden

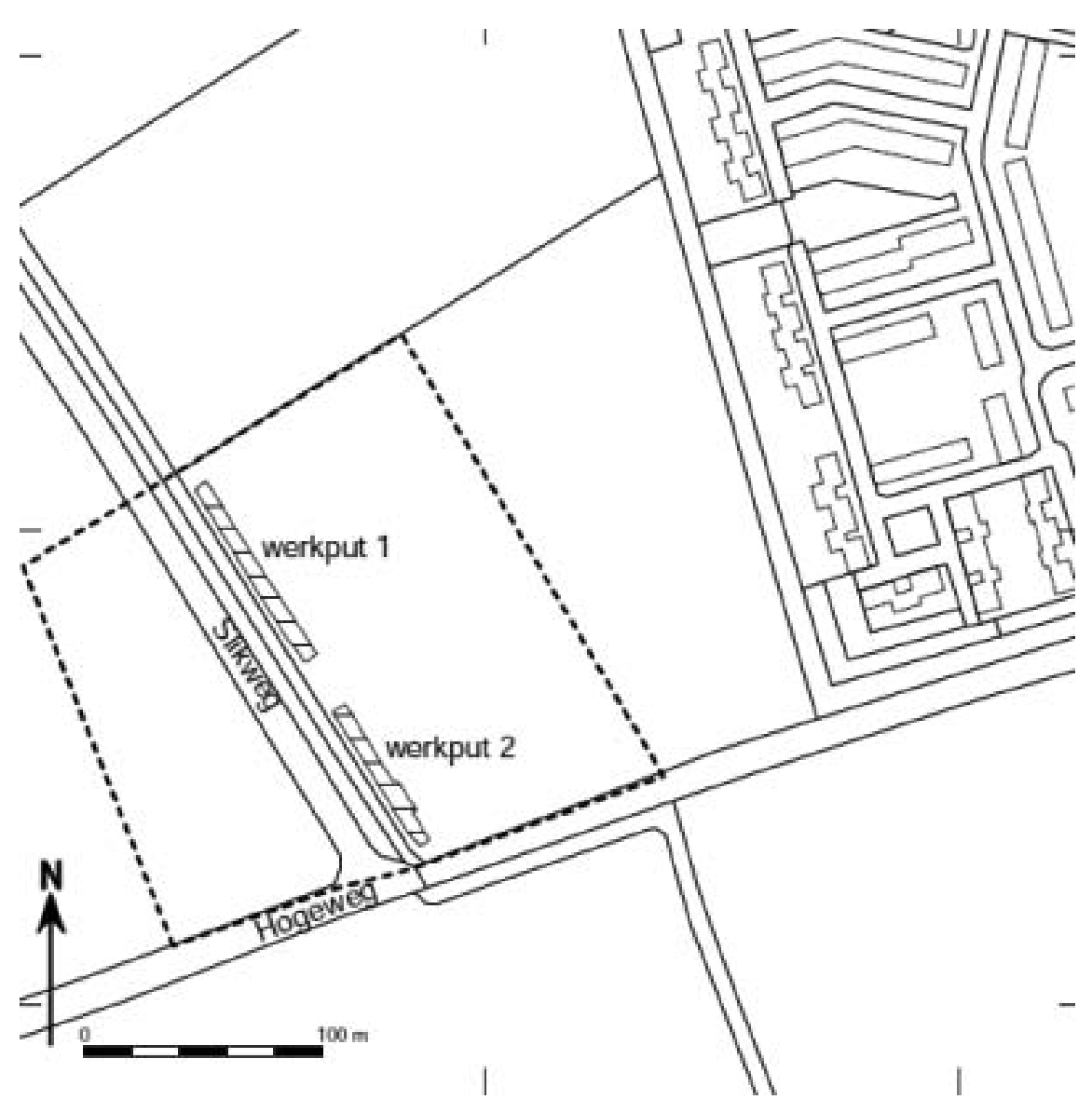

AFBEELDING 2 De locatie van de werkputten. 


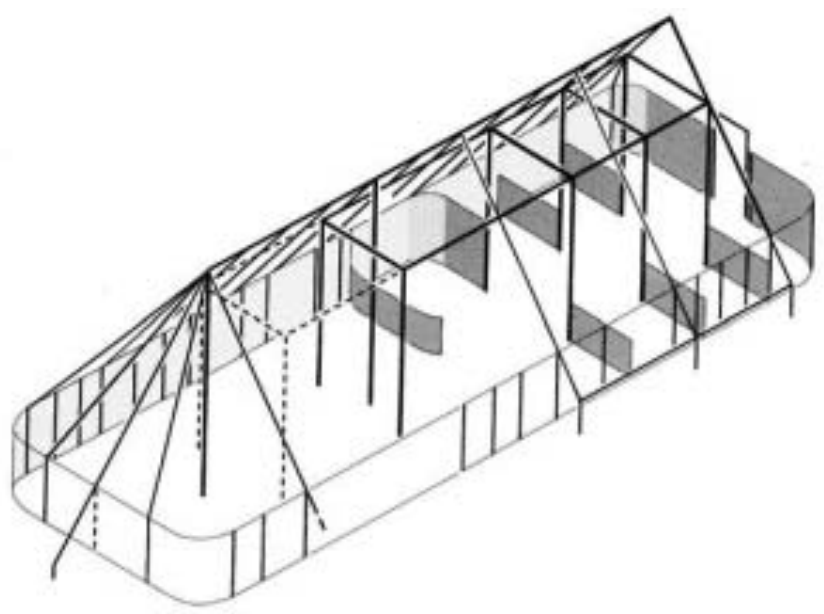

AFBEELDING 3 Reconstructie van een woonstalboerderij van de vindplaats Spijkenisse 17-30 (Vroege IJzertijd; naar Van Trierum 1992, afb. 34).

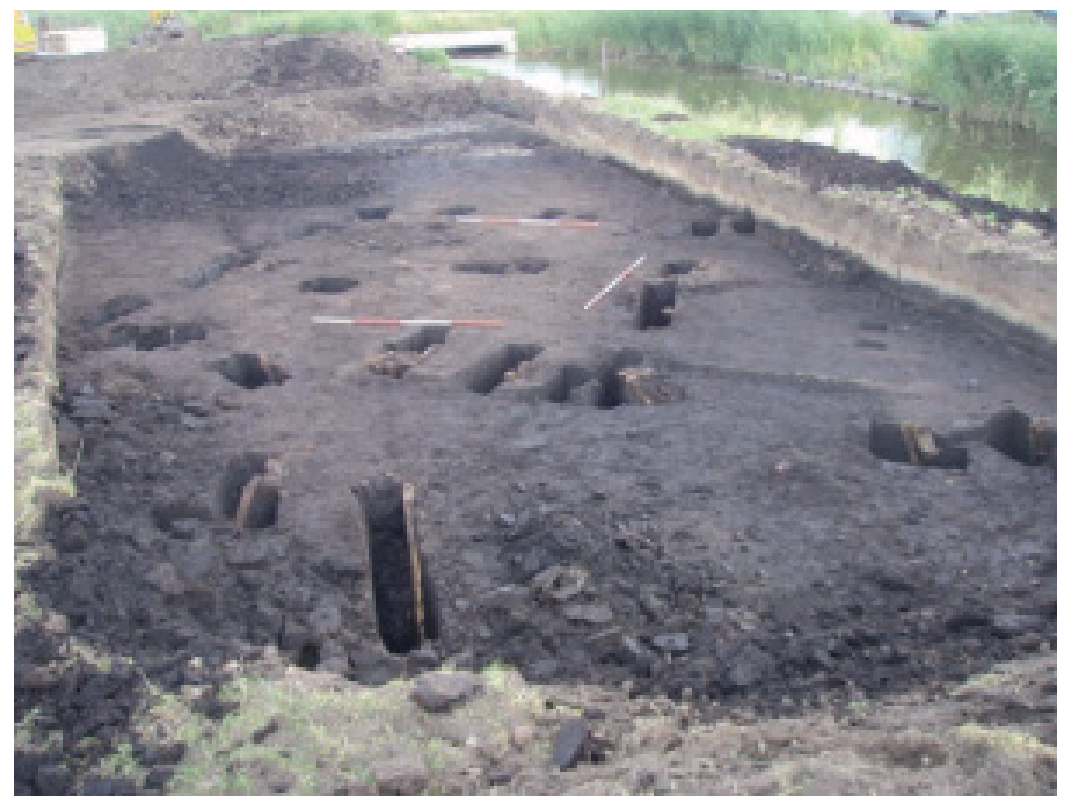

AFBEELDING 4 Dewoonstalboerderij tijdens het veldwerk. 
bevinden zich stijlen die later zullen zijn toegevoegd. Daarmee zal de levensduur van de boerderij verlengd zijn.

\subsection{Twee fasen}

De vindplaats dateert uit het begin van de Late IJzertijd. De eerste bewoningsfase is de fase van de woonstalboerderij, rond 210-200 v. Chr. De tweede fase wordt gekenmerkt door de 11 haard- en/of stookplaatsen. De locatie is dan in gebruik genomen als ambachtszone. Dit is aan het begin van de ze eeuw v. Chr.

\subsection{Haard-en/of stookplaatsen}

Een bijzonder aspect van de opgraving langs de Dalle, is de aanwezigheid van maar liefst 11 haarden/ of stookplaatsen. Dankzij het specialistisch onderzoek kan een differentiatie binnen de haardplaatsen worden aangetoond: er zijn onder andere sporen van voedselbereiding en graanverwerking. Een zeer bijzondere vondst uit één van de haardplaatsen is een goudfragment (goudlegering van $60 \%$ goud). Daarnaast is er is bijna $50 \mathrm{~kg}$ handgevormd aardewerk op de vindplaats verzameld, waar minimaal 115 potten uit herleid konden worden. Dit is uitzonderlijk hoog voor één huishouden. In combinatie met de vele haardplaatsen wordt daarom een ambachtelijke zone verondersteld.

\subsection{Bier- of lijmproductie}

Er zijn duidelijke aanwijzingen voor een locale productie op de vindplaats. Op het aardewerk is bij verschillende scherven een wit aankoeksel aangetroffen. Het onderzochte residu blijkt een onverkoold mengsel van eiwitten en suikers te zijn. Dit kan enerzijds afkomstig zijn van een waterige vloeistof met suikers en eiwitten, zoals bier. Anderzijds kan het afkomstig zijn van de opslag van non-food materiaal, zoals lijm van beenderen of huiden. Uit het botanisch onderzoek is gebleken dat gerst in de nabijheid van de vindplaats is verbouwd. Dit is een argument voor een bierproductie. Daarnaast wijst het vele aangetroffen botmateriaal op een productie van lijm. Vooralsnog kan geen keuze worden gemaakt tussen deze twee mogelijkheden. De vele haardplaatsen en het hoge minimale aantal stuks aardewerk bevestigen echter dat de vindplaats in gebruik is geweest als ambachtszone. Dit zal na de bewoningsfase zijn geweest.

\section{Context}

Al vanaf de Vroege IJzertijd (800-50o v. Chr.) komt bewoning voor op het eiland Voorne-Putten. In deze periode worden boerderijen neergezet op veenbultjes, in de buurt van stromend water. Door stagnatie van de natuurlijke ontwatering wordt het gebied in de loop van de 6e eeuw v. Chr. te nat voor bewoning. 
In de Midden-IJzertijd (500-250 voor Chr.) bestaat hetzelfde bewoningsbeeld, maar in tegenstelling tot de voorgaande periode droogt het gebied sterker uit. Op veel plaatsen veraard de veenbodem, waardoor meer gebieden met grassen tot ontwikkeling kunnen komen. Daarnaast behoud het gebied wel het waterrijke karakter. Rond $400 \mathrm{v}$. Chr. wordt het gebied bewoond en ook nu worden de hogere delen in het landschap, in de omgeving van stromend water gebruikt voor de boerderijen (woonstalhuizen). Deze boerderijen liggen geësoleerd en verspreid in het veenlandschap. Er wordt uitgegaan van een boerderij met een erf er direct omheen; één boerderijplaats beslaat ongeveer $25^{-} 35 \times 40-50 \mathrm{~m}$. Er zijn tot nu toe 53 vindplaatsen uit deze periode op Putten bekend. Wederom wordt het gebied verlaten als het landschap te nat wordt.

In de Late IJzertijd (250-12 voor Chr.) is het verspreidingsgebied van de nederzettingen toegenomen ten opzichte van de voorgaande perioden. De bewoning vindt nu voornamelijk plaats op de hogere zandige delen. In de Romeinse tijd verandert weinig. Ook nu vindt bewoning plaats op de hogere en zandige delen in het landschap, hoewel een klein aantal vindplaatsen in het veen is aangetroffen. Vanaf de Late IJzertijd was het veengebied in gebruik als extensief weidegebied. Deze situatie bleef bestaan tot in de Middeleeuwen.

\section{Onderzoeksvragen}

Bij deze opgraving zijn verschillende onderzoeksvragen gesteld, die zijn beantwoord op basis van hetgeen in de werkputten is aangetroffen:

- Gaat het bij de vindplaats om één aaneengesloten vondstniveau? Of zijn er vondst- en spoorloze gebieden aanwezig binnen het areaal van de vindplaats? Zijn er meerdere erven aanwezig in het onderzoeksgebied?

- Is er een fasering in de sporen aan te brengen? En als er inderdaad meerdere erven aanwezig zijn, is dan een chronologie ervan vast te stellen? Of zijn de erven gelijktijdig? Bij de datering van de vindplaats dienen de mogelijkheden van ${ }_{14} \mathrm{C}$-dateringen en dendrochronologische dateringen ten volle te worden benut. Dendrochronologie hoeft niet alleen voor het absoluut dateren waardevolle informatie op te leveren; ook het relatief dateren van samenstellende elementen biedt waardevolle perspectieven.

- Wat kan er worden gezegd over de grondstofvoorziening (hout, steen en dergelijke)?

- Wat kan er worden gezegd over de voedseleconomie? Omdat delen van de site niet meer beschikbaar zijn voor onderzoek en omdat de conserveringsomstandigheden voor organisch materiaal ernstig zijn verslechterd 
sinds de verlaging van het polderpeil in de jaren tachtig dienen de mogelijkheden om de botanische en zoölogische component te onderzoeken ten volle te worden benut. Het onderzoek daarvan kan ook gegevens leveren over de ontwikkeling door de tijd van het landschap ter plekke van de vindplaats.

- Wat is de positie van de vindplaats in het nederzettingssysteem van de Midden-IJzertijd op Putten?

\section{Methoden}

Voor het fysisch geografisch onderzoek is gebruik gemaakt van gedocumenteerde profielwanden en kolomopnamen in de putwanden. De positie, lengte en diepte van de verschillende profielen was afhankelijk van het doel waarvoor de werkput is aangelegd. De profielen zijn handmatig opgeschaafd en vervolgens ingekrast en gedocumenteerd. Hierbij zijn zowel lithologische lagen als archeologisch relevante lagen onderscheiden, zoals vegetatiehorizonten, cultuurlagen en eventuele sporen.

De beschrijving van het aardewerk is ingevoerd in een Ms-Access database. Voor het aardewerk zijn de technologische en morfologische kenmerken beschreven van fragmenten groter dan $4 \mathrm{~cm}^{2}$. Hieronder worden verstaan kenmerken als scherftype (rand, wand, schouder, buik, bodem en indet. [een fragment waarbij een deel van de buiten- of binnenzijde ontbreekt]), mageringssoort, wandafwerking, bakmilieu, wanddikte, diameter van rand of bodem, randtype, bodemtype, potvorm, versiering, mate van verwering en periodisering. Het minimum aantal individuen is bepaald aan de hand van de randfragmenten.

Het dierlijk materiaal is met de hand verzameld. Bij de determinatie van het botmateriaal is gebruik gemaakt van de vergelijkingscollectie van Archeoplan Eco te Delft. Bij de determinatie van de dierlijke resten is zoveel mogelijk informatie verzameld. Dit houdt in dat van elk botfragment - indien mogelijk gegevens zijn genoteerd met betrekking tot dierklasse, soort, skeletelement, leeftijd, sexe, fragmentatie, afmeting en specifieke kenmerken zoals hak- of snijsporen en sporen van verbranding, vraat of pathologische aandoeningen. De gegevens van het onderzoek zijn opgeslagen in databestanden die zijn opgebouwd conform het Laboratoriumprotocol Archeozoölogie.

De monsters voor het botanisch macrorestenonderzoek zijn in twee volumes verdeeld. Een volume van 0,5 liter is gezeefd over een zeef met een maaswijdte van $0,25 \mathrm{~mm}$. Verder is 4,5 liter sediment gezeefd over een zeef met een maaswijdte van $0,5 \mathrm{~mm}$. De twee uitzonderingen hierop zijn monsters 115 en 
189; van de eerstgenoemde is 0,5 liter gezeefd over zeven met een maaswijdte van 0,25 en $0.5 \mathrm{~mm}$. Van monster 189 is 0,5 liter gezeefd over een zeef met een maaswijdte van $0,25 \mathrm{~mm}$. De residuen van alle fracties zijn vervolgens bekeken onder een binoculair met een vergroting van maximaal $50 \times$. Voor determinatie van de vruchten en zaden is gebruik gemaakt van de digitale zadenatlas, de 'Zadenatlas der Nederlandsche Flora' en de Bestimmungsschlüssel für Subfossile Juncus-Samen und Gramineen-Früchte.

\section{Data}

- Data gedeponeerd bij DANS - DoI:10.17026/dans-x5d-dx3f

- Periode: Late IJzertijd (250 - 12 v. Chr.); Romeinse tijd (12 vC - 450 na Chr.)

\subsection{Aardewerk}

Het gevonden handgevormde aardewerk valt globaal te dateren is in de late Midden-IJzertijd en de Late IJzertijd. Opvallende kenmerken voor het aardewerk uit de Late IJzertijd zijn een horizontale rij van nagel- of vingerindrukken direct onder de potrand of op de hals, evenals aan de buitenzijde van de wand ter hoogte van de bodemplaat. De hals is kort, soms met een lichte knik uitgebogen, en de randen zijn vaak rond, maar puntige, verdikte, afgeplatte en hoekige randen komen ook voor. Het aardewerk is in deze fase verschraald met potgruis en in mindere mate met organisch materiaal, gemiddeld $10 \%$.

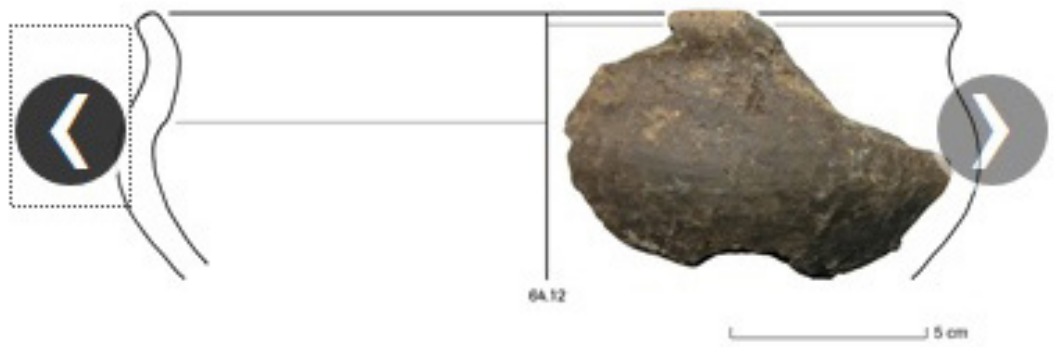

Midden IJzertijd (AW64-12) 
Het handgevormde aardewerk uit Romeinse contexten varieert sterk van het aardewerk uit de Late IJzertijd. Gemiddeld is slechts $4 \%$ van de wandfragmenten versierd, waarbij de versiering altijd vanaf de bovenzijde van de pot is aangebracht en daaronder op de buik niet aanwezig is. Indien randen zijn versierd is dit vaak op de buitenkant van de rand (gemiddeld $55 \%$ ) en in mindere mate op de bovenkant van de rand (40\%), terwijl een combinatie van beide in gemiddeld $15 \%$ van de gevallen voorkomt. Fragmenten zijn vrijwel niet besmeten. De randen zijn rond van vorm, maar afgeplatte en puntige randen komen ook voor, evenals in mindere mate randen met een lip. De halzen zijn vaak langer dan bij de vormen uit de Late IJzertijd. Voor de magering van de klei is voornamelijk potgruis gebruikt (circa $75 \%$ ), maar ook organische magering is toegepast (circa $25 \%$ ).

In werkput 1 zijn in totaal 49 fragmenten aardewerk aangetroffen met een totaalgewicht van 269 gram, waarvan $57 \%$ gruis, afkomstig uit vier sporen. Uit werkput 2 zijn 3.080 fragmenten aardewerk afkomstig met een totaalgewicht van 48 kilogram. Het aardewerk is in vrij hoge mate gefragmenteerd: $17 \%$ (543 stuks) is als gruis beschouwd en te klein om nader te determineren (kleiner dan $4 \mathrm{~cm}^{2}$ ). Het gemiddelde gewicht van deze groep ligt op 2,2 gram. Voor de overige groep van determineerbare fragmenten ( 2.537 stuks) ligt het gemiddelde gewicht per scherf op 18,6 gram.

\subsection{Archeozoölogisch onderzoek}

Op een aantal sites in Midden Delfland en Voorne-Putten na, lijken de bewoners niet op grote schaal cultuurgewassen verbouwd te hebben. Daarentegen lijkt een specialisatie in veeteelt op te treden. Een verklaring daarvoor zou gezocht kunnen worden in de geografische ligging van de onderzochte sites.

Het grootse deel van de dierlijke component van het dieet bestaat uit vlees van gedomesticeerde dieren. Maar liefst $70 \%$ van de tot op soort gebrachte fragmenten behoort toe aan rund, hetgeen correleert met $75 \%$ van het totale gewicht. Rundvlees werd dus het meest gegeten, gevolgd door het vlees van schaap en/of geit. Het lijkt erop dat varken slechts sporadisch gegeten werd. Mogelijk stond ook het vlees van edelhert op het menu. Resten van hond zijn eveneens aangetroffen. Honden zijn geen consumptiesoorten, maar hebben andere functies gehad. Honden zijn mogelijk als waakdier gebruikt. De resten van paard zouden mogelijk als consumptieresten geïnterpreteerd kunnen worden, aangezien het algemene beeld van de consumptie van paard in de IJzertijd vooralsnog onduidelijk is. Paarden hebben mogelijk ook als rij- en lastdier gefunctioneerd. Vogel- en visresten zijn niet aangetroffen. 


\begin{tabular}{|c|c|c|c|c|c|c|c|c|}
\hline \multirow[b]{2}{*}{ Klasse } & \multirow[b]{2}{*}{ Nederlandse naam } & \multicolumn{2}{|c|}{ werkput 1} & \multicolumn{2}{|c|}{ werkput 2} & \multirow[b]{2}{*}{ Eindtotaal $\mathrm{N}$} & \multirow[b]{2}{*}{ Eindtotaal G } & \multirow[b]{2}{*}{ Latjinse naam } \\
\hline & & $\mathrm{N}$ & G & $\mathrm{N}$ & G & & & \\
\hline \multirow[t]{11}{*}{ Zoogdier } & Rund & 7 & 332,5 & 154 & 4523,5 & 161 & 4856,0 & Bos taurus \\
\hline & Schaap/Geit & 3 & 34,5 & 39 & 148,0 & 42 & 182,5 & Ovis aries/Capra hircus \\
\hline & Varken & $\cdot$ & - & 20 & 170,0 & 20 & 170,0 & Sus domesticus \\
\hline & Paard & 1 & 60,0 & 3 & 52,0 & 4 & 112,0 & Equus caballus \\
\hline & Partied skelet & 31 & 8741,5 & - & - & 31 & 8741,5 & \\
\hline & Edelhert & - & - & 1 & 43.5 & 1 & 43,5 & Cervus elaphus \\
\hline & Hond & 1 & 3,0 & - & - & 1 & 3,0 & Canis familianis \\
\hline & middelgroot zoogdier & - & - & 27 & 70,5 & 27 & 70,5 & medium mammal (indet) \\
\hline & groot zoogdier & 5 & 47,0 & 92 & 762,0 & 97 & 809,0 & large mammal (indet) \\
\hline & zoogdier, niet te determineren & 24 & 39,0 & 470 & 745,0 & 494 & 784,0 & mammial, indet. \\
\hline & Eindtotaal & 41 & 516,0 & BO6 & 6514,5 & 847 & 15772,0 & \\
\hline
\end{tabular}

AFBEELDING $6 \quad$ Soortenspectrum voor Spijkenisse. $N$ : aantal, G: gewicht in grammen.

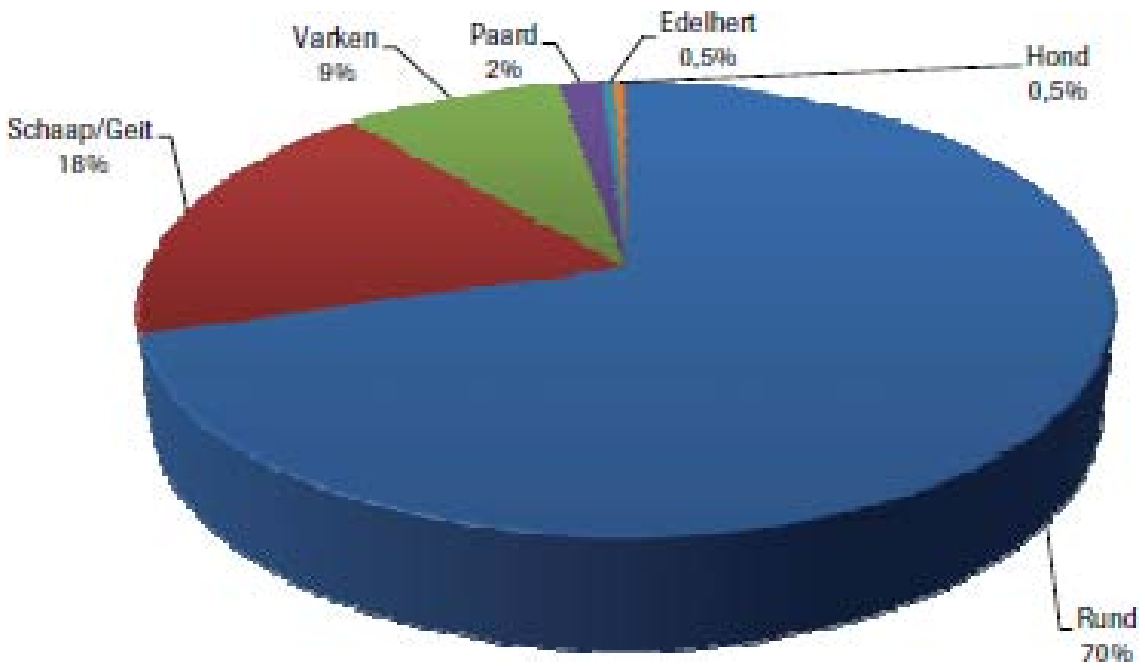

AFBEELDING $7 \quad$ Soortenspectrum voor Spijkenisse in percentages.

\subsection{Archeobotanisch onderzoek}

Het doel van het botanisch onderzoek is inzicht te verkrijgen in de ontwikkeling van de lokale vegetatie in en om het woonstalhuis en tevens een beeld te krijgen van de lokale voedseleconomie en het aandeel van akkerbouw, veeteelt en visconsumptie daarin. Het veengebied rond Spijkenisse is vanaf de Vroege-IJzertijd bewoond geweest. Geulvorming zorgde voor ontwatering van het veenlandschap, waarna bewoning mogelijk was. Het onderzoeksgebied raakte echter pas intensief bewoond tijdens de Midden-IJzertijd. Bewoning vond plaats op de hoger gelegen delen in het veenlandschap en veelal direct 
aan of in de directe nabijheid van het geulenstelsel dat daar ontstaan is door een transgressie (= het landinwaarts trekken van de zee) tijdens de MiddenIJzertijd. De bevolking bestond grotendeels uit zelfvoorzienende boeren die leefden in woonstalhuizen. Deze boerderijen lagen solitair verspreid in het veenlandschap in de onmiddellijke nabijheid van de zogenaamde Duinkerke Igeulen.

Granen. Over het algemeen wordt aangenomen dat landbouwproducten als granen in de IJzertijd lokaal verbouwd en geconsumeerd werden. De meest voorkomende graanmacroresten die gevonden zijn in haardplaatsen van Spijkenisse vindplaats, zijn afkomstig van emmertarwe (Triticum dicoccum). Daarnaast zijn er veel verkoolde resten gevonden van (bedekte) gerst (Hordeum vulgare). Net als emmer is gerst een veelvoorkomend graan in de IJzertijd.

Tenslotte zijn er enkele verkoolde graankorrels van haver (Avena) en rogge (Secale cereale) gevonden. Het betreft hier waarschijnlijk resten van gedomesticeerde haver, maar omdat er geen goed bewaarde kafresten gevonden zijn, is het niet uit te sluiten dat het hier oot (Avena fatua) betreft. Naast haver is ook rogge een nieuwe graansoort in de IJzertijd. Het is echter niet zeker of beide graansoorten als cultuurgewas gebruikt werden in de IJzertijd. Hoewel beide in deze periode in Duitsland en Frankrijk wel verbouwd werden, is het waarschijnlijker dat haver en rogge als akkeronkruid voorkwamen op graanakkers in de IJzertijd in Spijkenisse.

Graslanden. In de buurt van het woonstalhuis hebben graslanden met daarin struisgras (Agrostis sp.) en geknikte vossenstaart (Alopecurus geniculatus) gestaan. Beide grassoorten komen met name voor in graslanden die in de winter en in het voorjaar onder water staan. Geknikte vossenstaart in het bijzonder is een soort die voorkomt in graslanden waar tred niet ongewoon is. In dit gebied groeit deze soort op niet te arme veengronden. In graslanden komen vaak naast echte grassen (Poaceae) juist ook veel andere kruidensoorten voor. Naast veel (verkoolde) graszaden zijn er in Spijkenisse ook enkele andere planten gevonden die op graslanden aangetroffen kunnen worden. Zo zijn botanische macroresten van tweerijige zegge (Carex disticha) gevonden. Ook deze soort gedijt goed op natte plekken in graslanden en is zouttolerant ten opzichte van andere zeggensoorten. Kortom, in de buurt van de onderzoekslocaties zijn graslanden aanwezig geweest die in de winter en voorjaar onder water hebben gestaan, maar in de zomer droog vielen.

Heide en veen. De vele veenmosblaadjes (Sphagnum sp.) in de monsters laten zien dat in het gebied veen veelvuldig voorkwam. Met name in monster 130 zijn deze veenmosblaadjes in overvloede aanwezig. Tevens zijn in monster 115 een groot aantal blaadjes gevonden van hei (Ericaceae), wat aangeeft dat hei ook in de directe omgeving van Spijkenisse voorkwam. 


\section{Conclusies}

Bewoning vond plaats op de hogere delen in het veenlandschap, op zogeheten veenbultjes. Het veenpakket moet voldoende ontwaterd zijn geweest waardoor bewoning mogelijk was. Het woonstalhuis heeft gelegen in een omgeving met een nat grasland met ruigte-vegetatie (waaronder melde) dat in gebruik was als weidegrond. De oude vegetatie is hier herhaaldelijk afgebrand, waardoor de vruchtbaarheid van de grond wordt verbeterd en de hergroei van de vegetatie versnelt. Hierdoor verbeteren de graasomstandigheden voor het vee.

De opgegraven huisplattegrond heeft uit een woondeel, een hal en een staldeel bestaan. Hoewel de plattegrond niet volledig meer aanwezig is en feitelijk alleen het woondeel en de hal zijn opgegraven, kan het staldeel aan de westzijde van het huis worden verondersteld. Ook het aangetroffen botmateriaal wijst op de aanwezigheid van een stal. Tijdens de bewoning is er zowel aan veeteelt als aan akkerbouw gedaan.

Een bijzonder verschijnsel zijn de elf haard- en/of stookplaatsen, van verschillende formaten. Bij een onderlinge vergelijking van deze haardplaatsen, zijn er meer overeenkomsten dan verschillen aanwezig. De gelaagde opbouw is in alle sporen aanwezig. Eén haardplaats is veel langer gebruikt: deze is na het verlaten van de boerderij door de bewoners, wederom in gebruik genomen tijdens de ambachtsfase en in omvang uitgebreid. De overige haardplaatsen zullen alleen gedurende de ambachtsfase in gebruik zijn geweest.

Naast voedselbereiding en graanverwerking zijn er duidelijke aanwijzingen voor een locale productie op de vindplaats. Op het aardewerk is bij verschillende scherven een wit aankoeksel aangetroffen; dit residu is nader onderzocht. Het kan enerzijds afkomstig zijn van een waterige vloeistof met suikers en eiwitten, zoals bier. Anderzijds kan het afkomstig zijn van de opslag van non-food materiaal, zoals lijm van beenderen of huiden. Uit het botanisch onderzoek is gebleken dat gerst in de nabijheid van de vindplaats is verbouwd. Dit is een argument voor een bierproductie. Daarnaast wijst het vele aangetroffen botmateriaal op een productie van lijm. Vooralsnog kan geen keuze worden gemaakt tussen deze twee mogelijkheden.

Vanuit de gedachte van 'de biografie van een huis', waarbij slechts één generatie gebruik maakt van een woonhuis, en de relatief korte levensduur van de gebruikte houtsoorten, zal de bewoning van de aangetroffen woonstalboerderij ca. 10 tot maximaal 20 jaar geduurd hebben. De volgende generatie kan in de nabijheid een nieuwe boerderij gebouwd hebben. De huidige onderzoekslocatie kan echter nog steeds geschikt zijn voor ambachtelijke activiteiten: door de bewoning is de locatie geprepareerd tot een stevig plateau. Bewoners uit de directe omgeving hebben de locatie voor een bier- of lijmproductie gebruikt. 
Dit verklaart het grote aantal haardplaatsen en de weinig onderlinge verschillen tussen deze haardplaatsen. De verlaten houten boerderij zal mogelijk voor beschutting hebben gezorgd en deels voor brandstof. De ontbrekende palen uit de plattegrond zouden opzettelijk verwijderd kunnen zijn. Dit roept echter direct de vraag op waarom dan niet al het hout gebruikt is. Misschien zijn de palen bovengronds afgekapt en is de rest van het hout vergaan in de oxidatiezone van het veen. Hier zijn echter geen bewijzen voor. Kapsporen zijn op de nu aangetroffen palen niet meer zichtbaar. De vindplaats heeft nog niet al haar geheimen prijs gegeven.

\section{Literatuur}

Abbink, A.A. (1999). Make it and Breakit: the cycles of pottery - A study of the technology, form, function and use of pottery from the settlements at Uitgeest-Groot Dorregeest en Schagen-Muggenburg 1, Roman Period, North Holland, the Netherlands. Archeological Studies Leiden University: https://openaccess.leidenuniv.nl/handle/1887/13510.

Bakels, C.C. (1997). De cultuurgewassen van de Nederlandse Prehistorie, 5400 v.C. - 12 v.C. In: A.C. Zeven (Ed.), De introductie van onze cultuurplanten en hun begeleiders, van het Neolithicum tot $1500 A D$ (pp. 15-12). Wageningen: Vereniging voor Landbouwgeschiedenis.

Bult, E.J. (1983). Midden-Delfland, een archeologische kartering, inventarisatie, waardering en bewoningsgeschiedenis, Amersfoort/Maasland (NAR 2).

Dorst, M.C. (2007). Spijkenisse, 'Vierambachtenboezem, watergangverbreding gemaal Putten.' Een bureaustudie en een verkennend inventariserend veldonderzoek door middel van grondboringen met aanvullende karterende boringen, Rotterdam (воовrapporten 395): http://dx.doi.org/10.17026/dans-z96-7k49.

Kodde, S. (2007). Living On The Edge. Rurale bouwtradities in het West-Nederlandse kustgebied gedurende de Late IJzertijd en de Romeinse periode, Amsterdam (ongepubliceerde doctoraalscriptie Vrije Universiteit Amsterdam).

Mulder, E.F.J. de Geluk, M.C. Ritsema, I.L. Westerhoff, W.E. \& Wong, T.E. (2003). De ondergrond van Nederland. Groningen: Wolters-Noordhoff.

Trierum, M.C.van (1992). Nederzettingen uit de IJzertijd en de Romeinse Tijd op VoornePutten, IJsselmonde en een deel van de Hoeksche Waard. In A.B. Döbken (Ed.) BOOR-balans 2 - Bijdragen aan de bewoningsgeschiedenis van het Maasmondgebied (pp. 15-102). Rotterdam. 